\title{
50 LAT KONWENCJI WIEDEŃSKIEJ O PRAWIE TRAKTATÓW W ŚWIETLE POLSKIEJ PRAKTYKI TRAKTATOWEJ \\ Ogólnopolska Konferencja Naukowa \\ WARSZAWA, 23 MAJA 2019 R.
}

W dniu 23 maja 2019 r. na Zamku Królewskim w Warszawie odbyła się Ogólnopolska Konferencja Naukowa nt. 50 lat Konwencji wiedeńskiej o prawie traktatów w świetle polskiej praktyki traktatowej. Organizatorem tego wydarzenia był Departament Prawno-Traktatowy Ministerstwa Spraw Zagranicznych Rzeczypospolitej Polskiej, a patronat honorowy nad nim objął Prezydent Rzeczypospolitej Polskiej Andrzej Duda. Podkreślenia wymaga fakt, że konferencja została zorganizowana $\mathrm{w} 50$. rocznicę przyjęcia konwencji, dokładnie w dniu jej otwarcia do podpisu.

Konferencję otworzył w imieniu Ministra Spraw Zagranicznych Rzeczypospolitej Polskiej dr hab. Piotr Wawrzyk, Wiceminister Spraw Zagranicznych, który witając gości podkreślił, że celem tego naukowego spotkania jest zwrócenie uwagi na współczesne znaczenie jednej z najważniejszych umów międzynarodowych, jaką jest Konwencja wiedeńska o prawie traktatów z 1969 r., ze szczególnym uwzględnieniem polskiej praktyki traktatowej. $\mathrm{W}$ trakcie swojego wystąpienia P. Wawrzyk zwrócił uwagę, że wydarzenie wpisuje się $\mathrm{w}$ działania Polski związane $\mathrm{z}$ promowaniem poszanowania dla prawa międzynarodowego, stanowiącego zarazem dewizę niestałego członkostwa naszego państwa w Radzie Bezpieczeństwa w latach 2018-2019. W swoim przemówieniu nawiązał także do przypadającej w tym roku rocznicy 100-lecia polskiej polityki traktatowej, wskazując jednocześnie, że w tym okresie Polska podpisała ponad 6 tys. umów dwustronnych oraz około 1,3 tys. umów wielostronnych ${ }^{1}$.

Następnie dr Anna Surówka-Pasek, Podsekretarz Stanu w Kancelarii Prezydenta, przywitała uczestników wydarzenia w imieniu Prezydenta RP oraz odczytała okolicznościowy list Prezydenta do zgromadzonych, podkreślający

1 Zob. Biuro Rzecznika Prasowego Ministerstwo Spraw Zagranicznych, Na Zamku Królewskim o prawie traktatów, https://www.gov.pl/web/dyplomacja/na-zamku-krolewskim-o-prawie-traktatow [dostęp: 24.05.2019 r.]. 
znaczenie Konwencji wiedeńskiej o prawie traktatów, zarówno dla polskiej, jak i międzynarodowej, polityki traktowej.

W konferencji honorowy udział wzięli członkowie polskiej delegacji na Konferencję Wiedeńską: prof. dr hab. Maria Frankowska, prof. dr hab. Renata Szafarz, Andrzej Makarewicz oraz Alicja Werner-Makarewicz. W ich imieniu głos zabrała prof. dr hab. Renata Szafarz, która wygłosiła referat na temat przebiegu negocjacji i prac podczas obu sesji Konferencji Wiedeńskiej w 1968 i 1969 r. oraz udziału w nich polskiej delegacji. Następnie wiceminister P. Wawrzyk wyraził podziękowania gościom honorowym za ich aktywny wkład w prace nad konwencją.

Okolicznościowy referat pt. Miejsce i rola kodeksu prawa traktatów w międzynarodowej $i$ krajowej przestrzeni prawnej, otwierający część merytoryczną konferencji, wygłosił prof. dr hab. Roman Kwiecień (UJ). W swoim wystąpieniu zwrócił uwagę na rolę Konwencji wiedeńskiej jako swoistego kodeksu prawa traktatów. Podkreślił, że zwyczaj międzynarodowy został "przekuty" w trwałą i solidną kodyfikację prawa międzynarodowego, która aż do dzisiaj dobrze służy aktorom sceny międzynarodowej.

Po wygłoszeniu referatu okolicznościowego odbyły się trzy panele. Pierwszy z nich, zatytułowany: Wybrane aspekty stosowania umów międzynarodowych, moderował dr Piotr Rychlik (Dyrektor Departamentu Prawno-Traktatowego MSZ RP). Pierwszy referat $w$ tym panelu wygłosiła prof. dr hab. Anna Wyrozumska (UŁ) pt. Memorandum of Understanding a traktaty, w którym stwierdziła, że Memorandum of Understanding są chętnie stosowane przez państwa, chociaż nie wywołują one skutku odpowiedzialności międzynarodowej, gdyż są tylko deklaracjami, oczekiwaniami stron. Podkreśliła, że nie są i długo nie będą konkurencją dla traktatów, pomimo działania zasady dobrej wiary w odniesieniu do obu rodzajów zdarzeń prawnomiędzynarodowych, gdyż różne są ich konsekwencje i skutki prawne. Drugi referat pt. Tymczasowe stosowanie umów międzynarodowych w świetle prawa międzynarodowego i polskiego zaprezentował prof. dr hab. Cezary Mik (UKSW). Zwrócił w nim uwagę, że tymczasowość stosowania umów jest zagadnieniem stosunkowo nowym w prawie międzynarodowym, ale zyskuje na znaczeniu i jest coraz częściej stosowane. Przyczyn tego stanu należy upatrywać w postępowym rozwoju prawa międzynarodowego, a także w ustawodawstwie krajowym implementującym normy prawa międzynarodowego.

Drugi panel, moderowany przez dr Konrada Marciniaka (Zastępcę Dyrektora Departamentu Prawno-Traktatowego Ministerstwa Spraw Zagranicznych), poświęcony był doświadczeniom administracji państwowej wobec wybranych zagadnień prawno-traktatowych. Swoimi doświadczeniami 
W zakresie praktyki traktatowej podzielili się: Krzysztof Masło (Dyrektor Departamentu Współpracy Międzynarodowej Ministerstwa Sprawiedliwości), Kamil Zawadzki (Naczelnik w Departamencie Prawnym Ministerstwa Środowiska) oraz Małgorzata Paprocka (Dyrektor Biura Prawa i Ustroju Kancelarii Prezydenta RP).

Ostatni panel konferencji, zatytułowany: Praktyka traktatowa UE oraz umowy przyjmowane przez organy międzynarodowe. Wybrane problemy, moderowany był przez prof. dr. hab. Jerzego Kranza (Akademia Leona Koźmińskiego). W tej części konferencji zaprezentowano dwa referaty. Pierwszy: Tacit Acceptance oraz decyzje COP/MOP, wygłosiła prof. Małgosia Fitzmaurice (Queen Mary University of London). Stwierdziła, że Tacit Acceptance jest procedurą i praktyką przyjętą $\mathrm{w}$ wielu organizacjach międzynarodowych, która jest niezbędna do ich sprawnego i rozwojowego funkcjonowania. Podkreśliła, że procedura ta jest stosowana na podstawie postanowień konkretnej konwencji i ma charakter kontraktualny pomiędzy państwami-stronami a organizacją międzynarodową. Drugi referat: Umowy międzynarodowe mieszane Unii Europejskiej a prawo traktatów, zaprezentowała dr hab. Monika Niedźwiedź (UJ). Prelegentka stwierdziła, że ta kategoria umów określana jest także jako najbardziej problematyczna, z uwagi na charakter prawny UE $\mathrm{w}$ obrocie prawnomiędzynarodowym, w tym z uwagi na ograniczony charakter kompetencji UE. Nie da się uniknąć podpisywania tego rodzaju umów, gdyż ta organizacja międzynarodowa nie ma kompetencji we wszystkich sprawach - część z nich należy do kompetencji państw członkowskich UE.

Po każdym panelu odbyła się dyskusja z udziałem licznie zebranych uczestników konferencji, w tym wielu specjalistów z zakresu prawa międzynarodowego.

Podsumowania konferencji dokonał Dyrektor Departamentu Prawno-Traktatowego MSZ, dr P. Rychlik, który jednocześnie podziękował uczestnikom spotkania za interesującą debatę naukową.

Jakub Szczepkowski*

* Mgr, adwokat; e-mail: jakubszczepkowski@gmail.com, ORCID ID: https:/ / orcid.org/ 0000-0002-2940-4055. 
